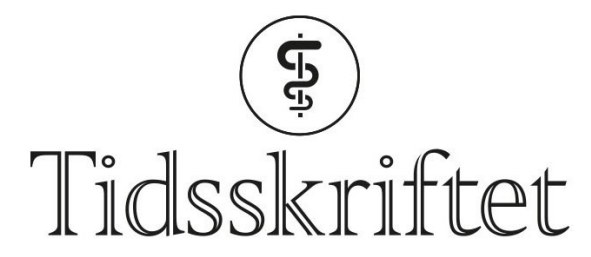

DEN NORSKE LEGEFORENING

\title{
Forside nr. 17/2020
}

\section{FORSIDE}

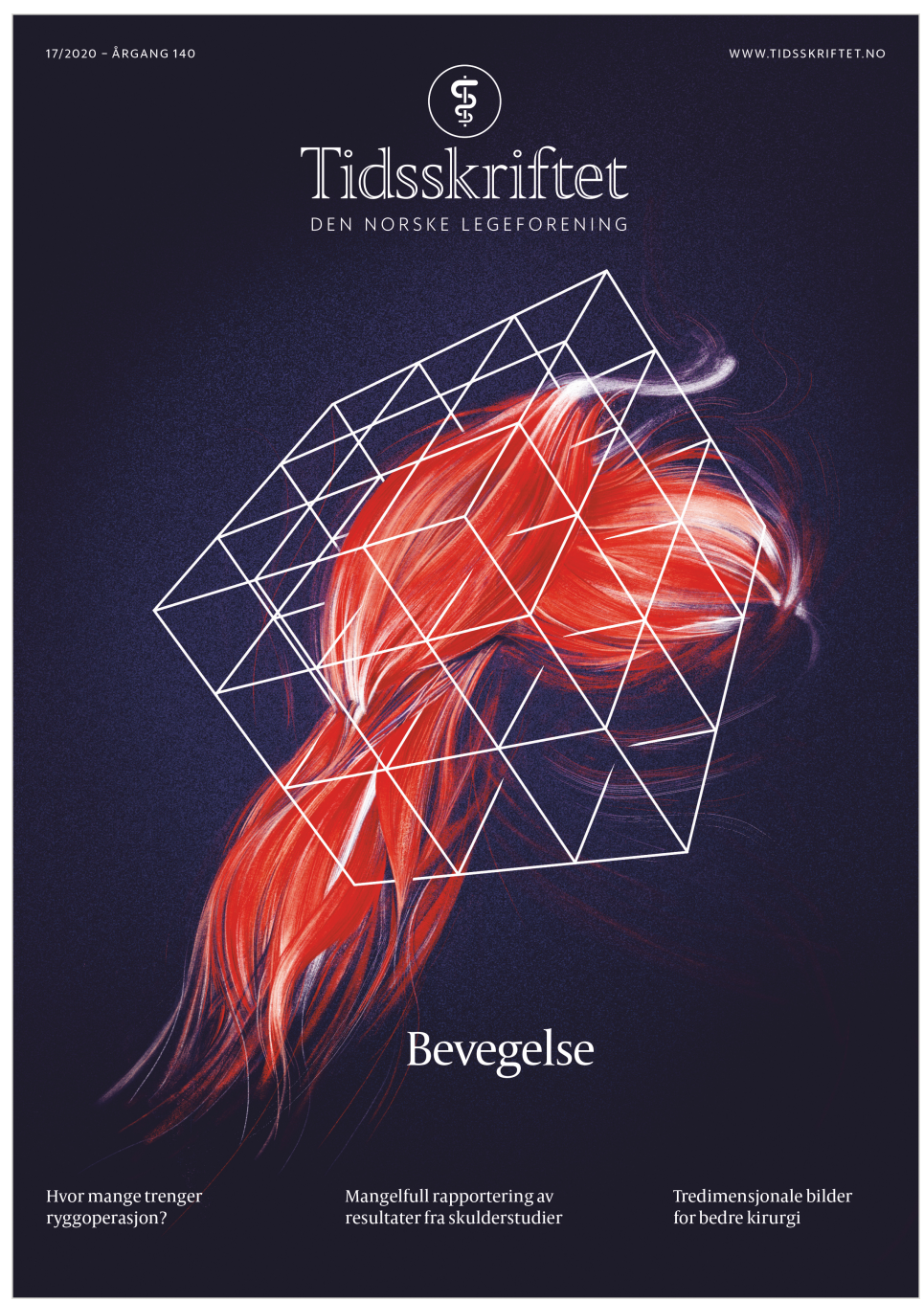

Illustrasjon (C) Miss Boo / Bente Jørgensen

I denne utgaven har vi flere vitenskapelige artikler der temaet er knyttet til kroppens bevegelsesapparat. «Bevegelse kan være så vakkert og uanstrengt», sier illustratør Bente Jørgensen. «Flytende som i en dans eller bevegelsene til et dypvannsdyr. Mens de anatomiske strukturene - muskler, sener og bein - ser så tunge og kompakte ut. Jeg likte tanken på å flette sammen disse to ideene om bevegelse i ett uttrykk: Buret med nåler og smerten som vender seg innover mot kroppen, begrenser den naturlige flyten i en bevegelse.»

Flere av Jørgensens arbeider kan du se her: www.missboo.no 
Publisert: 23. november 2020. Tidsskr Nor Legeforen. DOI: 10.4045/tidsskr.20.17.02 (C) Tidsskrift for Den norske legeforening 2020. Lastet ned fra tidsskriftet.no 